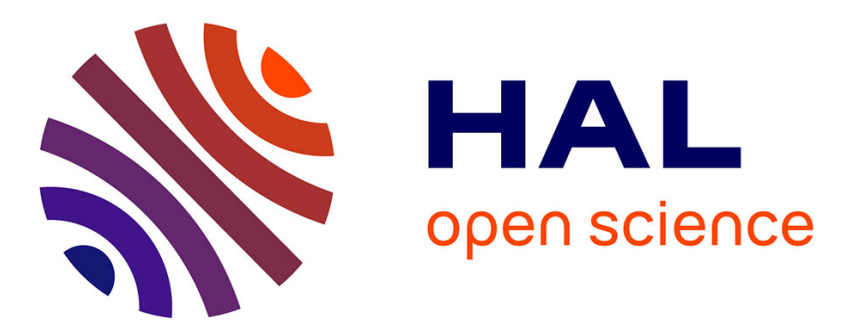

\title{
Study on Sm1.8Ce0.2CuO4-Ce0.9Gd0.1O1.95 composite cathode materials for intermediate temperature solid oxide fuel cell
}

Li-Ping Sun, Hui Zhao, Qiang Li, Li-Hua Huo, Jean-Paul Viricelle, Christophe Pijolat

\section{To cite this version:}

Li-Ping Sun, Hui Zhao, Qiang Li, Li-Hua Huo, Jean-Paul Viricelle, et al.. Study on Sm1.8Ce0.2CuO4Ce0.9Gd0.1O1.95 composite cathode materials for intermediate temperature solid oxide fuel cell. International Journal of Hydrogen Energy, 2011, 36 (19), pp.12555-12560. 10.1016/j.ijhydene.2011.07.001 . hal-00638336

\section{HAL Id: hal-00638336 https://hal.science/hal-00638336}

Submitted on 10 Nov 2011

HAL is a multi-disciplinary open access archive for the deposit and dissemination of scientific research documents, whether they are published or not. The documents may come from teaching and research institutions in France or abroad, or from public or private research centers.
L'archive ouverte pluridisciplinaire HAL, est destinée au dépôt et à la diffusion de documents scientifiques de niveau recherche, publiés ou non, émanant des établissements d'enseignement et de recherche français ou étrangers, des laboratoires publics ou privés. 


\title{
Study on $\mathrm{Sm}_{1.8} \mathrm{Ce}_{0.2} \mathrm{CuO}_{4}-\mathrm{Ce}_{0.9} \mathrm{Gd}_{0.1} \mathrm{O}_{1.95}$ composite cathode materials for intermediate temperature solid oxide fuel cell
}

\author{
Li-Ping Sun ${ }^{(1)}$, Hui ZhaO ${ }^{(1) *}$, QIANg Li ${ }^{(1)}$, Li-Hua HuO(1), Jean-PaUl Viricelle ${ }^{(2) \dagger}$, \\ Christophe PiJOlat ${ }^{(2)}$ \\ (1) Key Laboratory of Functional Inorganic Material Chemistry, Ministry of Education, \\ School of Chemistry and Materials Science, Heilongjiang University, Harbin 150080, \\ PR China \\ (2) Ecole Nationale Supérieure des Mines de Saint Etienne, Centre SPIN ; Département \\ PRESSIC ; LPMG -UMR CNRS 5148, 158 Cours Fauriel - 42023 Saint-Étienne Cedex \\ 2, France
}

\begin{abstract}
$\mathrm{Sm}_{1.8} \mathrm{Ce}_{0.2} \mathrm{CuO}_{4}-x \mathrm{Ce}_{0.9} \mathrm{Gd}_{0.1} \mathrm{O}_{1.95}$ (SCC- $x \mathrm{CGO}, x=0-12$ vol.\%) composite cathodes supported on $\mathrm{Ce}_{0.9} \mathrm{Gd}_{0.1} \mathrm{O}_{1.95}$ (CGO) electrolyte are studied for applications in IT-SOFCs. Results show that $\mathrm{Sm}_{1.8} \mathrm{Ce}_{0.2} \mathrm{CuO}_{4}$ material is chemically compatible with $\mathrm{Ce}_{0.9} \mathrm{Gd}_{0.1} \mathrm{O}_{1.95}$ at $1000{ }^{\circ} \mathrm{C}$. The composite electrode exhibits optimum microstructure and forms good contact with the electrolyte after sintering at $1000{ }^{\circ} \mathrm{C}$ for $4 \mathrm{~h}$. The polarization resistance $\left(R_{\mathrm{p}}\right)$ reduces to the minimum value of $0.17 \Omega \mathrm{cm}^{2}$ at $750{ }^{\circ} \mathrm{C}$ in air for SCC-CGOo6 composite cathode. The relationship between $R_{\mathrm{p}}$ and oxygen partial pressure indicates that the reaction rate-limiting step is the surface diffusion of the dissociative adsorbed oxygen on the composite cathode.
\end{abstract}

Keywords:

Solid oxide fuel cell (SOFC); $\mathrm{Sm}_{1.8} \mathrm{Ce}_{0.2} \mathrm{CuO}_{4}-\mathrm{Ce}_{0.9} \mathrm{Gd}_{0.1} \mathrm{O}_{1.95}(\mathrm{SCC}-\mathrm{CGO}$ ) composite cathode; Oxygen reduction reaction (ORR)

\section{Introduction}

Intermediate temperature solid oxide fuel cell (IT-SOFC) represents the research mainstream in the realm of solid oxide fuel cells. One major problem encountered in the developing ITSOFC is the slow dynamic oxygen reduction reaction (ORR) on traditional cathode in the intermediate temperature range. Therefore optimization of cathode performance is becoming essential [1], [2] and [3]. Perovskite structured materials (such as ( $\mathrm{La}, \mathrm{Sr})(\mathrm{Co}, \mathrm{Fe}) \mathrm{O}_{3}$, $\mathrm{Sm}_{0.5} \mathrm{Sr}_{0.5} \mathrm{CoO}_{3}, \mathrm{Ba}_{0.5} \mathrm{Sr}_{0.5} \mathrm{Co}_{0.8} \mathrm{Fe}_{0.2} \mathrm{O}_{3}$ ) are promising cathodes for IT-SOFCs, due to their high catalytic activity for ORR and considerable electronic conductivity [4], [5] and [6]. Unfortunately, these materials do not completely meet all the technical requirements (such as thermal expansion, ionic conductivity, mechanical stability), which prevent the rapid commercialization of the IT-SOFC system. Studies have shown that materials with $\mathrm{K}_{2} \mathrm{NiF}_{4}-$ type structure exhibited promising cathode properties in IT-SOFC system. Compared to their perovskite cousins, $\mathrm{K}_{2} \mathrm{NiF}_{4}$-type materials possess improved thermal stability, compatible thermal expansion coefficients with these commercially available electrolytes (YSZ, CGO, SDC et al.), and applauding oxygen diffusion and surface exchange coefficients [7], [8], [9] and [10]. Mauvy et al. studied $\mathrm{Ln}_{2} \mathrm{NiO}_{4+\delta}(\mathrm{Ln}=\mathrm{La}, \mathrm{Nd}, \mathrm{Pr})$ series materials, and found $\mathrm{Nd}_{1.95} \mathrm{NiO}_{4}$ exhibited promising electrode properties. The area-specific resistance (ASR) was $1.3 \Omega \mathrm{cm}^{2}$ at $700{ }^{\circ} \mathrm{C}[10]$. Li et al. reported that the ASR of $\mathrm{La}_{1.7} \mathrm{Sr}_{0.3} \mathrm{CuO}_{4}$ cathode was as low as $0.16 \Omega \mathrm{cm}^{2}$

\footnotetext{
* Corresponding author : zhaohuig8@yahoo.com

${ }^{\dagger}$ Corresponding author : viricelle@emse.fr
} 
at $700{ }^{\circ} \mathrm{C}$ in air [11]. Recently we reported the electrochemical performance of $\mathrm{Sm}_{2-\mathrm{x}} \mathrm{Ce}_{\mathrm{x}} \mathrm{CuO}_{4}$ and the ASR of $\mathrm{Sm}_{1.8} \mathrm{Ce}_{0.2} \mathrm{CuO}_{4}$ was $0.37 \Omega \mathrm{cm}^{2}$ at $750{ }^{\circ} \mathrm{C}$ in air [12].

It is believed that the cathode properties can be improved by increasing the triple phase boundary (TPB) formed on the electrolyte/electrode interface. Many studies have demonstrated that composite cathodes exhibited much lower polarization resistance than those single-phase ones [13], [14] and [15]. For example, Li et al. reported that the addition of CGO dramatically reduced the ASR of $\mathrm{La}_{1.6} \mathrm{Sr}_{0.4} \mathrm{NiO}_{4}$ (LSN) cathode from $2.93 \Omega \mathrm{cm}^{2}$ to $0.76 \Omega$ $\mathrm{cm}^{2}$ at $700{ }^{\circ} \mathrm{C}$ in air [16]. Cao et al. found that the combination of CGO into $\mathrm{Ba}_{1.2} \mathrm{Sr}_{0.8} \mathrm{CoO}_{4+\delta}$ (BSC1208) material lowers the ASR to $0.17 \Omega \mathrm{cm}^{2}$ at $750^{\circ} \mathrm{C}$ in air [17].

The aim of the present work is to improve the performance of the $\mathrm{Sm}_{1.8} \mathrm{Ce}_{0.2} \mathrm{CuO}_{4}$ (SCC) cathode. CGO was added in SCC to form SCC-CGO composite cathode. Chemical compatibility, microstructure evolution and electrochemical performance have been studied and analyzed in comparison with the pure SCC cathode.

\section{Experimental}

SCC powder was synthesized by glycine-nitrate combustion method with nitrate precursors of $\mathrm{Sm}\left(\mathrm{NO}_{3}\right)_{3}, \mathrm{Ce}\left(\mathrm{NO}_{3}\right)_{3}$ and $\mathrm{Cu}\left(\mathrm{NO}_{3}\right)_{2}$. Stoichiometric amount of the nitrates was dissolved in distilled water to form a precursor solution. Glycine was then added to the solution with a molar ratio of 2 glycine to 1 metal ions. The solution was subsequently heated until it was ignited to form powders. The powders were heated in air at $1000{ }^{\circ} \mathrm{C}$ for $12 \mathrm{~h}$ to form SCC powders.

The CGO powder was obtained from Rhodia Courbevoie (France). The CGO powders were pressed uniaxially at $220 \mathrm{MPa}$ and then sintered at $1400{ }^{\circ} \mathrm{C}$ for $10 \mathrm{~h}$ to form a densified pellet. The cathode slurry was prepared by thoroughly mixing the SCC and CGO powders with terpineol in different volume ratios, and subsequently painted on one side of the CGO electrolyte to form an electrode area of $1.0 \mathrm{~cm}^{2}$, used as working electrode (WE). Platinum paste was painted on the other side of the CGO pellet in symmetric configuration, as the counter electrode (CE). A Pt wire was used as reference electrode (RE) and put on the same side of the working electrode. The cathodes were first heated at $400{ }^{\circ} \mathrm{C}$ for $2 \mathrm{~h}$ to eliminate organic binders, followed by sintering at different temperatures for $4 \mathrm{~h}$ in air, with a heating/cooling rate of $3{ }^{\circ} \mathrm{C} \mathrm{min}{ }^{-1}$. The obtained cathodes were abbreviated as SCC-CGOo3 for $\mathrm{Sm}_{1.8} \mathrm{Ce}_{0.2} \mathrm{CuO}_{4}$ with the addition of 3 vol. \% CGO, SCC-CGOo6 for 6 vol.\% CGO, and so on.

The sample was characterized using X-ray diffraction instrument (Rigaku, D/MAX-3B) and scanning electron microscopy (SEM) (Hitachi, S-4700 FEG), respectively. The impedance spectrum was recorded over the frequency range $1 \mathrm{MHz}$ to $0.1 \mathrm{~Hz}$ using Autolab PGStat3o. The measurements were performed at $\mathrm{OCV}$ as a function of temperature $\left(550-750{ }^{\circ} \mathrm{C}\right)$ and oxygen partial pressure (in an $\mathrm{N}_{2} / \mathrm{O}_{2}$ mixed atmosphere). The DC polarization experiments were performed by the chronoamperometry methods, as that explained in Reference [8].

\section{Results and discussions}

It is known that the interfacial chemical reaction between cathode and electrolyte materials has dramatic effect on the electrochemical performance of SOFCs. The chemical compatibility of SCC material with CGO powders was first studied. Figure 1 shows XRD patterns of SCC, CGO and the SCC-CGO mixtures after calcined at $1000{ }^{\circ} \mathrm{C}$ for $4 \mathrm{~h}$. All the diffraction peaks were found to be exclusively related to SCC and CGO phases. There was no additional diffraction peak or shift of XRD patterns observed in the heat-treated SCC-CGO mixtures, which suggests that there is no obvious chemical reaction between SCC and CGO at $1000{ }^{\circ} \mathrm{C}$. Therefore it is concluded that the mixed SCC and CGO composite cathode is stable under the experimental conditions.

SEM images of the resulting SCC powder, the commercial CGO, the sintered SCC and SCCCGO cathodes are shown in Figure 2. It is evident from Figure $2 \mathrm{a}$ and $\mathrm{b}$ that the morphology of SCC powder is irregular and the grain size is about $2-3 \mu \mathrm{m}$. The commercial CGO powder exhibited a much smaller grain size (about 100-200 $\mathrm{nm}$ ) and more homogeneous grain size 
distribution. Compared to the sintered SCC cathode (Figure 2c), two kinds of particles with different morphologies were clearly observed in the SCC-CGO composite cathode (Figure 2d). The smaller spherical particles (less than $200 \mathrm{~nm}$ in diameter) are CGO and the bigger ones $(2-3 \mu \mathrm{m})$ with irregular shape are SCC particles. After sintered at $1000{ }^{\circ} \mathrm{C}, \mathrm{SCC}$ is clearly seen to be covered with submicron CGO particles. It is observed that the SCC-CGO electrode has a fine porous structure with continue SCC particles network. Strong adhesion has been formed between the electrolyte and the cathode layer with neither cracks nor uncontinuity points along the cathode-electrolyte interface (Figure 2e), and a highly porous morphology ensures unhindered gas diffusion. The thickness of the electrode layer and electrolyte are 20$25 \mu \mathrm{m}$ and $1 \mathrm{~mm}$, respectively.

Figure 3 is a typical electrochemical impedance spectra of SCC-CGOo6 cathode on CGO electrolyte measured at different temperatures in air. For simplicity, the contributions of the electrolyte and lead wires have been subtracted from the plot. From the impedance spectra, it was observed that two arcs located in the high-frequency zone and the low-frequency zone, respectively. These two arcs tended to merge into one depressed arc at high temperature. This suggested that the oxygen reduction reaction (ORR) over the electrode was composed of at least two different processes. The overall size of the two arcs was primarily attributed to the cathode area-specific resistance (ASR), which is widely used to describe the resistance terms related to electrode processes. As expected, the electrode ASR decreased reversely with the measuring temperature, showing that the electrode activity changed monotonously with the temperature. We can also observe from Figure 3 that the overall size of the first arc is relatively small, and the second one is dominated in the whole measurement temperature range.

The effect of CGO on the SCC cathode performance was further studied, and the measured EIS spectrum is shown in Figure 4. Clearly the addition of CGO reduced the overall size of the two arcs. In order to make it more clear, an equivalent circuit was used (Figure 4 inset), and the fitting results are given in the figure. Here $R_{\text {el }}$ represents the combination of electrolyte resistance, electrode ohmic resistance, lead resistance and contact resistance between cell and Pt mesh, $R_{\mathrm{H}}$ and $R_{\mathrm{L}}$ are the polarization resistance $\left(R_{\mathrm{p}}\right)$ corresponding to the high-frequency and low-frequency arcs, respectively. The ASR is the sum of $R_{\mathrm{H}}$ and $R_{\mathrm{L}}$. CPE is constant phase element whose value reflects the reaction mechanism of different electrode processes. In a previous study of SCC cathode, we have proved that the reaction rate-limiting step was charge-transfer reaction, which was represented by the high-frequency arc in the EIS spectrum. The calculated capacitance values were on the order of $10^{-3} \mathrm{~F}$ for the highfrequency arcs and $10^{-1} \mathrm{~F}$ for the low-frequency arcs, respectively [12]. Compared with SCC electrode, the addition of CGO to SCC electrode reduces dramatically the value of ASR, but the magnitude of CPE remains almost unchanged (Figure 4). It was found that the decrease of ASR for SCC-CGO composite cathode is mainly attributed by the reduction of $R_{\mathrm{H}}$, which means that the charge-transfer reaction occurred on the composite cathode surface has been greatly promoted. At the same time, the low-frequency arc becomes dominant in the impedance spectra and the values of $R_{\mathrm{L}}$ are larger than those of $R_{\mathrm{H}}$. This is different from SCC cathode. According to the fitting results, this difference indicates that the oxygen reduction mechanism has been changed with the addition of CGO to SCC, and the surface diffusion of the dissociative adsorbed oxygen becomes reaction rate-limiting step on the composite cathode.

The Arrhenius plots of the area-specific resistance (ASR) for the SCC electrodes with different contents of CGO are given in Figure 5. The ASR decreases first with the CGO content, and reaches a minimum at 6 vol.\% CGO, then increases again with the further increase of CGO contents. The ASR of SCC-CGOo6 composite electrode is only $0.17 \Omega \mathrm{cm}^{2}$ at $750{ }^{\circ} \mathrm{C}$, which is about two times smaller than that of pure SCC electrode at the same measuring temperature. The activation energy $\left(E_{\mathrm{a}}\right)$ calculated for the SCC-CGO composite cathodes is in the range of 1.09-1.25 eV, which is quiet smaller compared to the $1.68 \mathrm{eV}$ for pure SCC cathode. The enhancement of the cathode performance can be explained by following reasons: first as reported, $\mathrm{SCC}$ with $\mathrm{K}_{2} \mathrm{NiF}_{4}$-type structure is a kind of mixed ionic-electronic conductor, the oxygen reduction reaction occurs not only on the TPB layer but also on the whole surface of 
electrode. The adsorbed molecular oxygen is first reduced to oxygen ions, and then transfers toward the electrode-electrolyte interface and bulk electrolyte. The oxygen ions transfer ability is limited by the concentration of oxygen vacancies in cathode [19]. With the addition of CGO in the composite cathode, the oxygen ions transfer ability is improved and the electrochemical reaction zone is enlarged, therefore the charge-transfer reaction rate is promoted. This result confirms that CGO greatly enhances the electrochemical reaction rate through improving the concentration of oxygen vacancies in SCC-CGO composite cathode. Second, the adhesion behavior between the electrode and electrolyte is improved by the addition of CGO in SCC, thus optimizes the electrochemical performance of SCC-CGO electrode.

Concerning the worsen effect with the further addition of CGO, we propose that SCC particles will be surrounded by CGO particles with the increase of CGO loading concentration. These SCC particles will be isolated from each other. Therefore the continuity of the charge transport paths within the SCC contact network will be interrupted by the CGO particles, which is not an electronic conducting material. This interruption will result in blocking of electronic conduction and consequent decrease in the electrochemical performance. The similar result has been found before in the investigation of $\mathrm{SmBaCoFeO}_{5^{+} \delta}-\mathrm{Ce}_{0.9} \mathrm{Gd}_{0.1} \mathrm{O}_{1.95}$ and $\mathrm{Pr}_{0.7} \mathrm{Sr}_{0.3} \mathrm{Co}_{0.9} \mathrm{Cu}_{0.1} \mathrm{O}_{3-\delta}-\mathrm{Ce}_{0.8} \mathrm{Sm}_{0.2} \mathrm{O}_{1.9}$ composite cathodes [20] and [21].

The optimum content of CGO in SCC electrode (6 vol\% CGO in SCC) obtained in this work is quite different from that of other composite electrode (such as LSCF-GDC, PSCF-GDC) reported by some researchers, which explained by the effective medium percolation theory (EMPT) [22], [23] and [24]. This discrepancy may be caused due to the big difference of the CGO and SCC particles size. Previous modeling study has proved that for a cathode made of YSZ and strontium-doped $\mathrm{LaMnO}_{3}$ (LSM), the optima YSZ volume fraction ( $\left.\phi_{\mathrm{YSZ}}\right)$ with minimum polarization resistance depends heavily on the ratio of average grain size of YSZ (rio) to that of LSM (rel), which varies from $\phi_{\mathrm{YSZ}}=0.24$ for rio $/ \mathrm{rel}=0.2$ to $\phi_{\mathrm{YSZ}}=0.81$ for rio/rel $=5$ [25]. This modeling result implies that the optima YSZ volume fraction decreases rapidly with the reduced particle size. From the SEM result in Figure 2, it can be observed that the grain size of CGO powders is more than 10 times much smaller than that of SCC powders. According to the model, the optimal CGO volume fraction ( $\left.\phi_{\mathrm{CGO}}\right)$ with minimum polarization resistance should be lower than $10 \mathrm{vol} \%$. This deduction is coincidence with our experimental results.

In order to further clarify the electrochemical reaction mechanism on the composite cathode, impedance measurements were done as a function of oxygen partial pressure. As we known, the variation of $R_{\mathrm{p}}$ vs $\mathrm{PO}_{2}$ can be well described by the following law:

$$
R_{p}=R_{p}^{0} x\left(P_{O_{2}}\right)^{n}
$$

The $n$ values give information about the species involved in the electrode reactions [26] and [27]

$\begin{array}{ll}\mathrm{n}=1 & O_{2(\text { gas })} \rightarrow O_{2,(\text { gas })} \\ \mathrm{n}=1 & O_{2(\text { gas })} \rightarrow 2 O_{a d s .} \\ \mathrm{n}=1 / 2 & O_{a d s} \rightarrow O_{T P B} \\ \mathrm{n}=3 / 8 & O_{T P B}+e^{-} \rightarrow O_{T P B}^{-} \\ \mathrm{n}=1 / 8 & O_{T P B}^{-}+e^{-} \rightarrow O_{T P B}^{2-} \\ \mathrm{n}=0 & O_{T P B}^{2-}+V_{O}^{\bullet \bullet} \rightarrow O_{O}^{x}\end{array}$

The dependence of polarization resistance on oxygen partial pressure is shown in Figure 6. In the whole range of the oxygen partial pressure that measured, the value of $R_{\mathrm{H}}$ changed slowly with oxygen partial pressure, and the magnitude of $n$ is close to $1 / 8$, which suggests this process relates to the charge-transfer reaction at the TPB. On the other hand, a $0.41-0.42 P_{\mathrm{O}_{2}}$ dependency of $R_{\mathrm{L}}$ was observed. Considering that this value is close to $1 / 2$, which is related to 
the diffusion of the dissociative adsorbed oxygen on the cathode surface. It was observed that the polarization resistance of low-frequency arc is always larger than that of high-frequency arc. Therefore in this study, the surface diffusion of the dissociative adsorbed oxygen to the activated reaction sites was proved to be the major rate-limiting step in the whole range of measurement oxygen partial pressure.

Cathode overpotential is an important factor reflecting the electrode performance. It is observed that under the same current density, the cathode overpotential decrease with the increase amount of CGO (Figure 7). The SCC-CGOo6 cathode exhibits the best performance, when the current density reaches $200 \mathrm{~mA} \mathrm{~cm}^{-2}$ at $750^{\circ} \mathrm{C}$ in air, the cathode overpotential is $40 \mathrm{mV}$, which is much smaller than the reported $\mathrm{Sm}_{1.8} \mathrm{Ce}_{0.2} \mathrm{CuO}_{4}$ cathode material in literature [12]. At low overpotential (less than $20 \mathrm{mV}$ ), a linear expression, $i=i_{0} Z F \eta / R T$ can be expected, where $i$ is the current density, $i_{0}$ the exchange current density, $\eta$ the overpotential, and $F, R$ have their normal meanings, respectively. From the inverse of the derivative of $i$ against $\eta$, the ASR can be calculated. The value obtained for SCC-CGOo6 is $0.15 \Omega \mathrm{cm}^{2}$ at $750^{\circ} \mathrm{C}$, which is in agreement with the results obtained from the impedance measurement. Our results again prove that the polarization resistance can be reduced dramatically by forming a composite cathode.

\section{Conclusions}

In this article, SCC-CGO composite cathodes are prepared and characterized for SOFCs operating at reduced temperatures. No reaction was found between $\mathrm{Sm}_{1.8} \mathrm{Ce}_{0.2} \mathrm{CuO}_{4}$ and $\mathrm{CGO}$ electrolyte after heat-treatment at $1000{ }^{\circ} \mathrm{C}$ for $4 \mathrm{~h}$, indicating good chemical compatibility of these materials. The addition of CGO powders greatly improves the electrochemical performances of the composite cathodes, and the optimum composition is SCC-CGOo6 with the lowest area-specific resistance $0.17 \Omega \mathrm{cm}^{2}$ at $750^{\circ} \mathrm{C}$ in air. The rate-limiting step for oxygen reduction on the composite cathode is surface diffusion of the dissociative adsorbed oxygen. The highest current density is $200 \mathrm{~mA} \mathrm{~cm}-2$ at an overpotential of $40 \mathrm{mV}$ for the composite cathode. In a word, our results prove that SCC-CGO composite materials can be considered as promising cathodes for intermediate temperature SOFCs.

\section{Acknowledgements}

The Project was supported by National Natural Science Foundation of China (51072048) and Foundation of Heilongjiang Educational Committee (GZo9A204, 1152G027, 11531274, 11531285).

\section{References}

[1] V.V. Srdić, R.P. Omorjan and J. Seydel, Electrochemical performances of (La, $\mathrm{Sr}) \mathrm{CoO}_{3}$ cathode for zirconia-based solid oxide fuel cells. Mater Sci Eng B, 116 (2005), pp. 119124 .

[2] N.P. Brandon, S. Skinner and B.C. Steel, Recent advances in materials for fuel cells. Annu Rev Mater Res, 33 (2003), pp. 183-213.

[3] M.T. Colomer, B.C.H. Steele and J.A. Kilner, Structural and electrochemical properties of the $\mathrm{Sr}_{0.8} \mathrm{Ce}_{0.1} \mathrm{Fe}_{0.7} \mathrm{Co}_{0.3} \mathrm{O}_{3-\delta}$ perovskite as cathode material for ITSOFCs. Solid State Ionics, 147 (2002), pp. 41-48.

[4] M.S. Toprak, M. Darab, G.E. Syvertsen and M. Muhammed, Synthesis of nanostructured BSCF by oxalate co-precipitation - as potential cathode material for oxide fuel cells. Int J Hydrogen Energy, 35 (2010), pp. 9448-9454.

[5] Z. Shao and S.M. Halle, A high performance cathode for the next generation solid-oxide fuel cells. Nature, 431 (2004), pp. 170-173.

[6] Y.M. Kim, P. Kim-Lohsoontorn, S.W. Baek and J. Bae, Electrochemical performance of unsintered $\quad \mathrm{Ba}_{0.5} \mathrm{Sr}_{0.5} \mathrm{Co}_{0.8} \mathrm{Fe}_{0.2} \mathrm{O}_{3-\delta}, \quad \mathrm{La}_{0.6} \mathrm{Sr}_{0.4} \mathrm{Co}_{0.8} \mathrm{Fe}_{0.2} \mathrm{O}_{3-\delta}, \quad$ and $\mathrm{La}_{0.8} \mathrm{Sr}_{0.2} \mathrm{MnO}_{3-\delta}$ cathodes for metal-supported solid oxide fuel cells. Int J Hydrogen Energy, 36 (2011), pp. 3138-3146. 
[7] S.J. Skinner and J.A. Kilner, Oxygen diffusion and surface exchange in $\mathrm{La}_{2-x} \mathrm{Sr}_{x} \mathrm{NiO}_{4+\delta}$. Solid State Ionics, 135 (2000), pp. 709-712.

[8] M.A. Daroukh, V.V. Vashook, H. Ullmann, F. Tietzb and I.A. Raj, Oxides of the $\mathrm{AMO}_{3}$ and $\mathrm{A}_{2} \mathrm{MO}_{4}$-type: structural stability, electrical conductivity and thermal expansion. Solid State Ionics, 158 (2003), pp. 141-150.

[9] Y.S. Wang, H.W. Nie, S.R. Wang, T.L. Wen, U. Guth and V. Valshook, $\mathrm{A}_{2-\alpha} \mathrm{A}_{\alpha}{ }^{\prime} \mathrm{BO}_{4}$-type oxides as cathode materials for IT-SOFCs $\left(\mathrm{A}=\mathrm{Pr}, \mathrm{Sm} ; \mathrm{A}^{\prime}=\mathrm{Sr} ; \mathrm{B}=\mathrm{Fe}\right.$, Co. Mater Lett, 60 (2006), pp. 1174-1178.

[10] F. Mauvy, C. Lalanne, J.M. Bassat, J.C. Grenier, H. Zhao and P. Dordor, et al. Oxygen reduction on porous $\mathrm{Ln}_{2} \mathrm{NiO}_{4+\delta}$ electrodes. $J$ Eur Ceram Soc, 25 (2005), pp. 26692672.

[11] Q. Li, H. Zhao, L.H. Huo, L.P. Sun, X.L. Cheng and J.C. Grenier, Electrode properties of $\mathrm{Sr}$ doped $\mathrm{La}_{2} \mathrm{CuO}_{4}$ as new cathode material for intermediate-temperature SOFCs. Electrochem Commun, 9 (2007), pp. 1508-1512.

[12] L.P. Sun, L.H. Huo and H. Zhao, Synthesis and performance of $\mathrm{Sm}_{2-x} \mathrm{Ce}_{x} \mathrm{CuO}_{4}$ cathode materials for IT-SOFC. Chin J Inorg Chem, 23 (2007), pp. 1545-1549.

[13] S.G. Huang, C.Q. Peng and Z. Zong, A high-performance $\mathrm{Gd}_{0.8} \mathrm{Sr}_{0.2} \mathrm{CoO}_{3}-\mathrm{Ce}_{0.9} \mathrm{Gd}_{0.1} \mathrm{O}_{1.95}$ composite cathode for intermediate temperature solid oxide fuel cell. $J$ Power Sources, 176 (2008), pp. 102-106.

[14] B.W. Liu, Y. Zhang and L.M. Zhang, Characteristics of $\mathrm{Ba}_{0.5} \mathrm{Sr}_{0.5} \mathrm{Co}_{0.8} \mathrm{Fe}_{0.2} \mathrm{O}_{3-\delta^{-}}$ $\mathrm{La}_{0.9} \mathrm{Sr}_{0.1} \mathrm{Ga}_{0.8} \mathrm{Mg}_{0.2} \mathrm{O}_{3-\delta}$ composite cathode for solid oxide fuel cell. $J$ Power Sources, 175 (2008), pp. 189-195.

[15] Y.P. Fu, Electrochemical performance of $\mathrm{La}_{0.9} \mathrm{Sr}_{0.1} \mathrm{Co}_{0.8} \mathrm{Ni}_{0.2} \mathrm{O}_{3-\delta}-\mathrm{Ce}_{0.8} \mathrm{Sm}_{0.2} \mathrm{O}_{1.9}$ composite cathode for solid oxide fuel cells. Int $J$ Hydrogen Energy, 36 (2011), pp. 5574-5580.

[16] Q. Li, Y. Fan, H. Zhao and L.H. Huo, Preparation and electrochemical properties of composite cathode $\mathrm{La}_{1.6} \mathrm{Sr}_{0.4} \mathrm{NiO}_{4}-\mathrm{Ce}_{0.9} \mathrm{Gd}_{0.1} \mathrm{O}_{1.9}$ for ITSOFC. Chin $J$ Inorg Chem, 23 (2007), pp. 300-304.

[17] C. Jin and J. Liu, Preparation of $\mathrm{Ba}_{1.2} \mathrm{Sr}_{0.8} \mathrm{CoO}_{4+\delta} \quad \mathrm{K}_{2} \mathrm{NiF}_{4}$-type structure oxide and cathodic behavioral of $\mathrm{Ba}_{1.2} \mathrm{Sr}_{0.8} \mathrm{CoO}_{4+\delta}-\mathrm{GDC}$ composite cathode for intermediate temperature solid oxide fuel cells. $J$ Alloys Compd, 474 (2009), pp. 573-577.

[18] H. Zhao, L.H. Huo, L.P. Sun, L.J. Yu, S. Gao and J.G. Zhao, Preparation, chemical stability and electrochemical properties of LSCF-CBO composite cathodes. Mater Chem Phys, 88 (2004), pp. 160-166.

[19] S.Y. Li, Z. Lü, B. Wei, X.Q. Huang, J.P. Miao and Z.G. Liu, et al. Performances of $\mathrm{Ba}_{0.5} \mathrm{Sr}_{0.5} \mathrm{Co}_{0.6} \mathrm{Fe}_{0.4} \mathrm{O}_{3-\delta}-\mathrm{Ce}_{0.8} \mathrm{Sm}_{0.2} \mathrm{O}_{1.9}$ composite cathode materials for IT-SOFC. $J$ Alloys Compd, 448 (2008), pp. 116-121.

[20] S.Q. Lü, G.H. Long, Y. Ji, X.W. Meng and C.C. Sun, Characterization of $\mathrm{SmBaCoFeO}_{5+\delta^{-}}$ $\mathrm{Ce}_{0.9} \mathrm{Gd}_{0.1} \mathrm{O}_{1.95}$ composite cathodes for intermediate-temperature solid oxide fuel cells. Int J Hydrogen Energy, 35 (2010), pp. 7930-7935.

[21] C.J. Zhu, X.M. Liu, D. Xu, D.J. Wang, D.T. Yan and L. Pei, et al. Electrochemical performance of $\mathrm{Pr}_{0.7} \mathrm{Sr}_{0.3} \mathrm{Co}_{0.9} \mathrm{Cu}_{0.1} \mathrm{O}_{3-\delta}-\mathrm{Ce}_{0.8} \mathrm{Sm}_{0.2} \mathrm{O}_{1.9}$ composite cathodes in intermediate-temperature solid oxide fuel cells. J Power Sources, 185 (2008), pp. 212216.

[22] E.P. Murray, M.J. Sever and S.A. Barnett, Electrochemical performance of (La, $\mathrm{Sr})(\mathrm{CoFe}) \mathrm{O}_{3}-(\mathrm{Ce}, \mathrm{Gd}) \mathrm{O}_{3}$ composite cathodes. Solid State Ionics, 148 (2002), pp. 2734 .

[23] P.K. Patro, T. Delahaye and E. Bouyer, Development of $\mathrm{Pr}_{0.58} \mathrm{Sr}_{0.4} \mathrm{Fe}_{0.8} \mathrm{Co}_{0.2} \mathrm{O}_{3-\delta}-\mathrm{GDC}$ composite cathode for solid oxide fuel cell (SOFC) application. Solid State Ionics, 181 (2010), pp. 1378-1386.

[24] V. Dusastre and J.A. Kilner, Optimisation of composite cathodes for intermediate temperature SOFC applications. Solid State Ionics, 126 (1999), pp. 163-174.

[25] X.J. Chen, S.H. Chan and K.A. Khor, Simulation of a composite cathode in solid oxide fuel cells. Electrochim Acta, 49 (2004), pp. 1851-1861. 
[26] R.A. De Souza and J.A. Kilner, Oxygen transport in $\mathrm{La}_{1-x} \mathrm{Sr}_{x} \mathrm{Mn}_{1-y} \mathrm{Co}_{y} \mathrm{O}_{3 \pm \delta}$ perovskites: Part I. Oxygen tracer diffusion. Solid State Ionics, 106 (1998), pp. 175-187.

[27] R.A. De Souza and J.A. Kilner, Oxygen transport in $\mathrm{La}_{1-x} \mathrm{Sr}_{x} \mathrm{Mn}_{1-y} \mathrm{Co}_{y} \mathrm{O}_{3 \pm \delta}$ perovskites: Part II. Oxygen surface exchange. Solid State Ionics, 126 (1999), pp. 153-161.

\section{Figures}

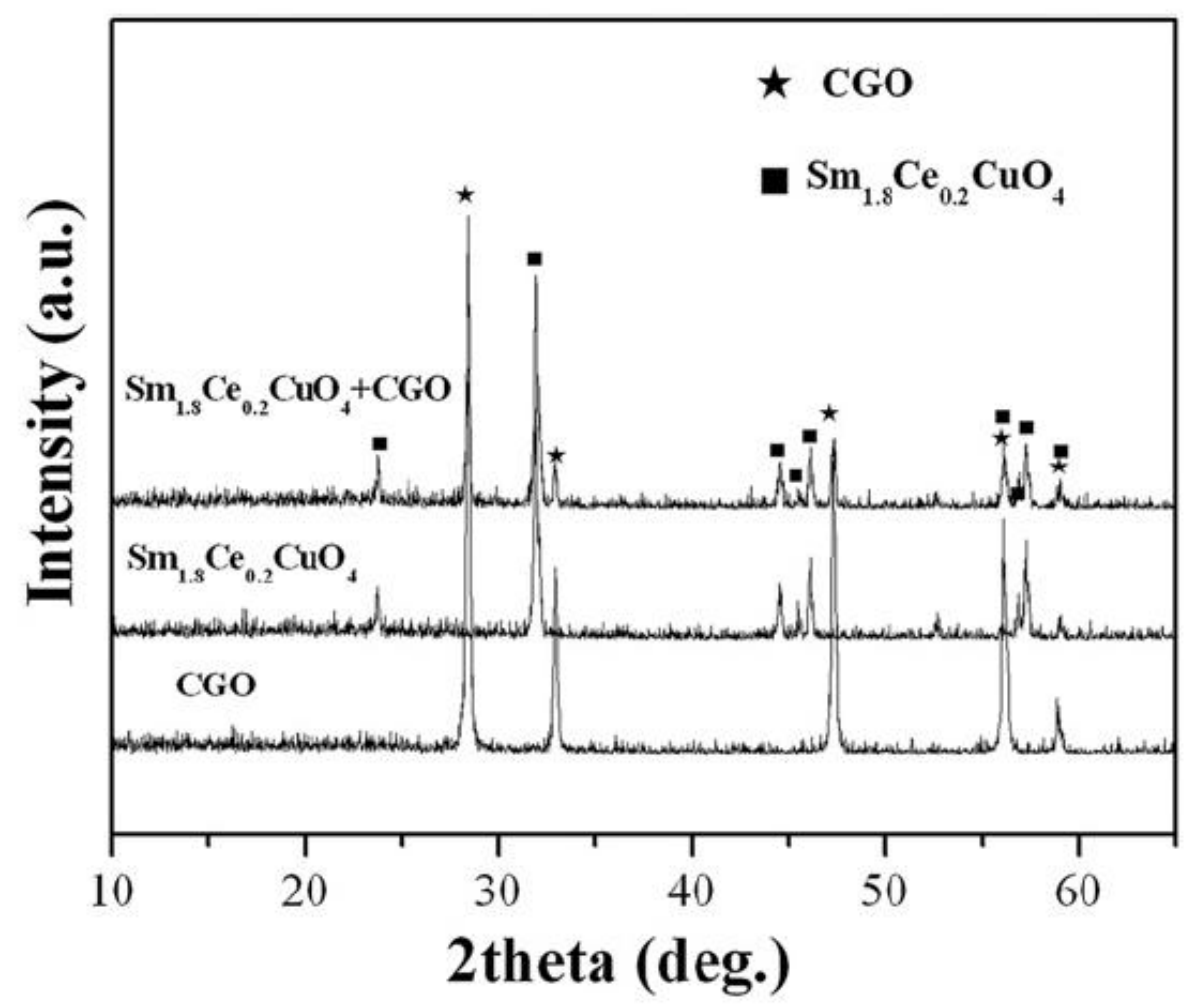

Figure 1: XRD patterns of the as-prepared SCC, CGO and SCC-CGO mixed powders after sintering at $1000{ }^{\circ} \mathrm{C}$ for $4 \mathrm{~h}$ in air. 


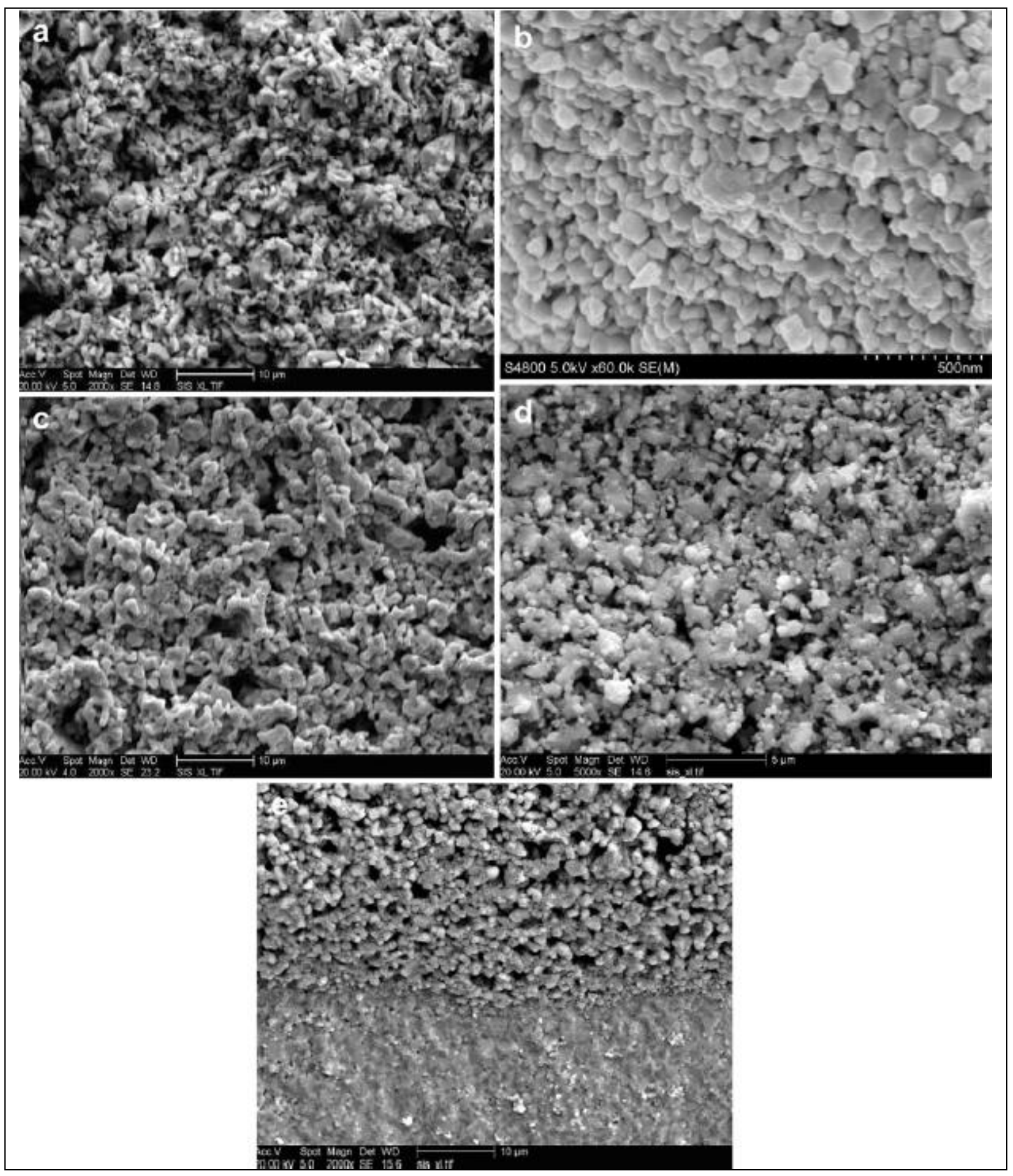

Figure 2: SEM images of as-prepared SCC powders (a), commercial CGO powders (b), SCC cathode (c), SCCCGO composite cathode (d) and cross-sectional micrograph (e). 
International Journal of Hydrogen Energy, 2011, 36(19), 12555-12560, doi: 10.1016/j.ijhydene.2011.07.001

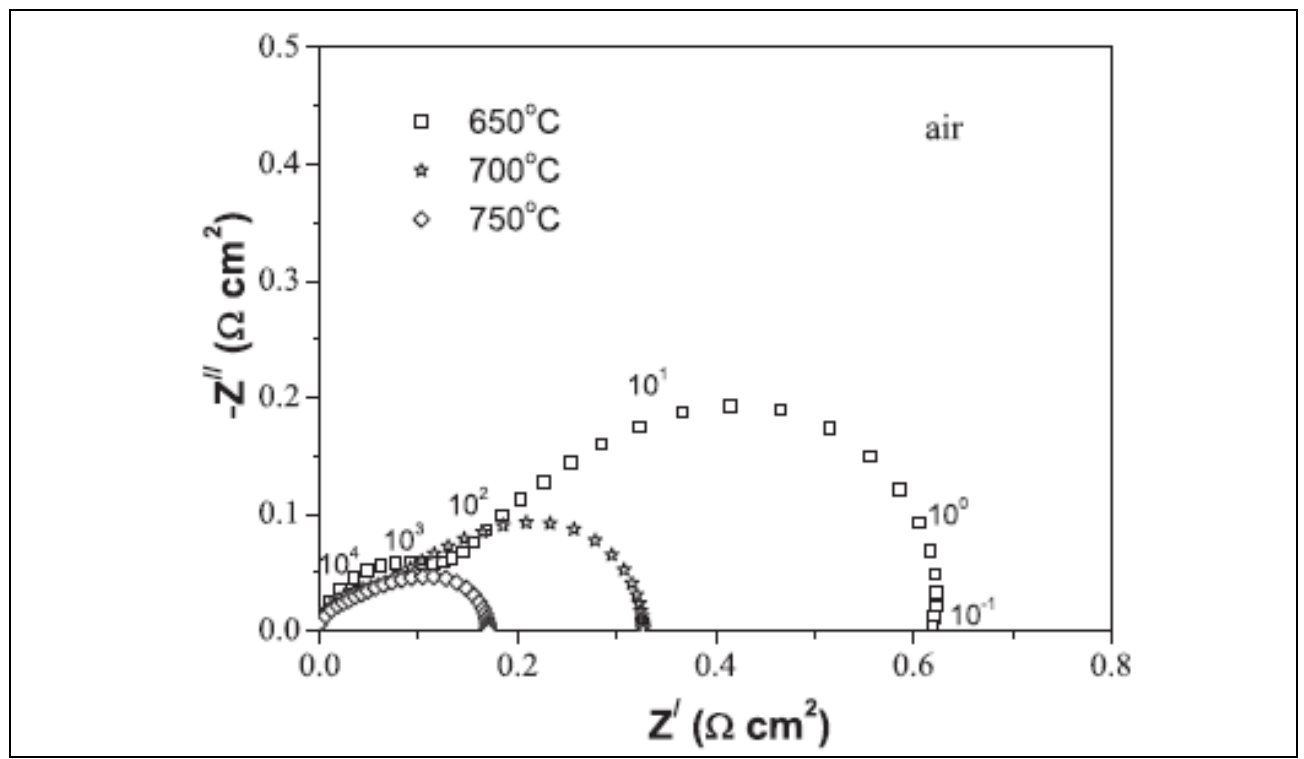

Figure 3: Impedance spectra of SCC-CGOo6 cathode measured in air at various temperatures.

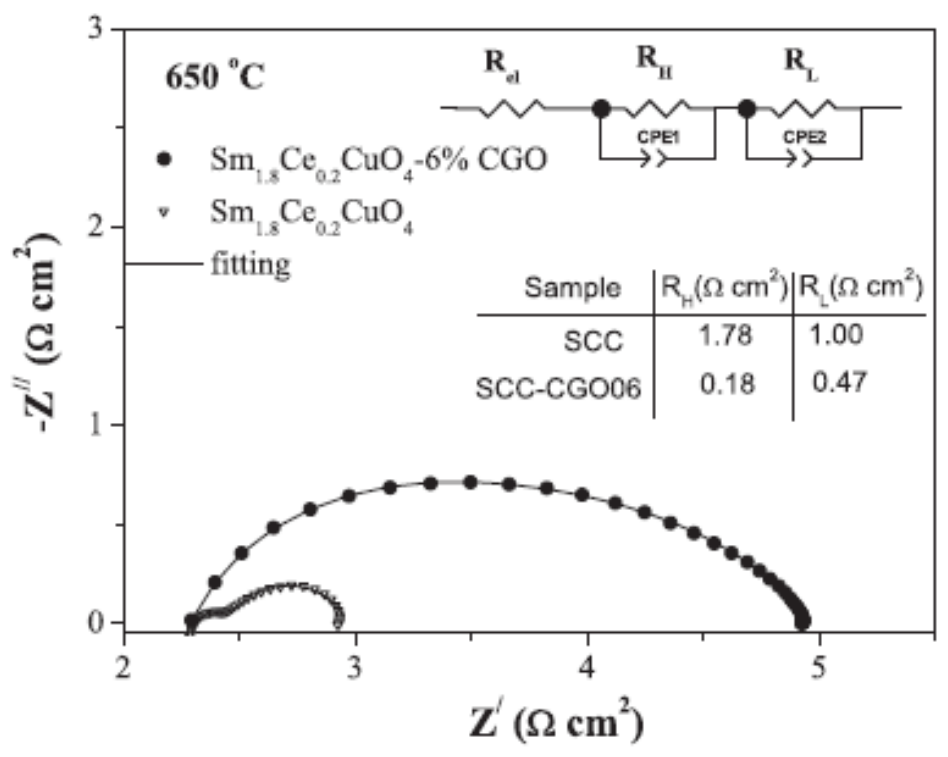

Figure 4: Impedance spectra of SCC cathode and SCC-CGOo6 composite cathode measured at $650^{\circ} \mathrm{C}$. 
International Journal of Hydrogen Energy, 2011, 36(19), 12555-12560, doi: 10.1016/j.ijhydene.2011.07.001

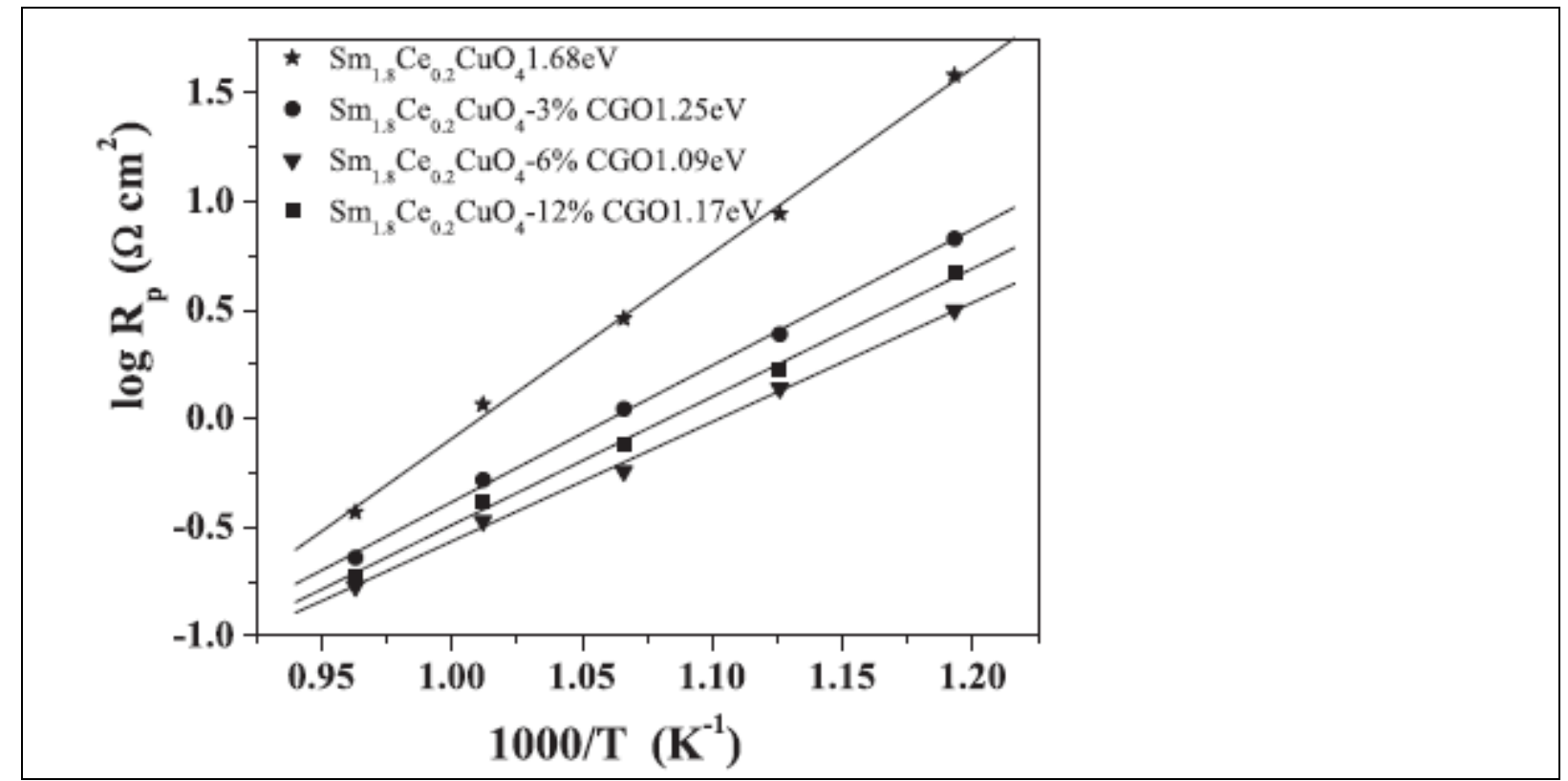

Figure 5: Arrhenius plots of the polarization resistance for various SCC-CGO composite cathodes measured in air.

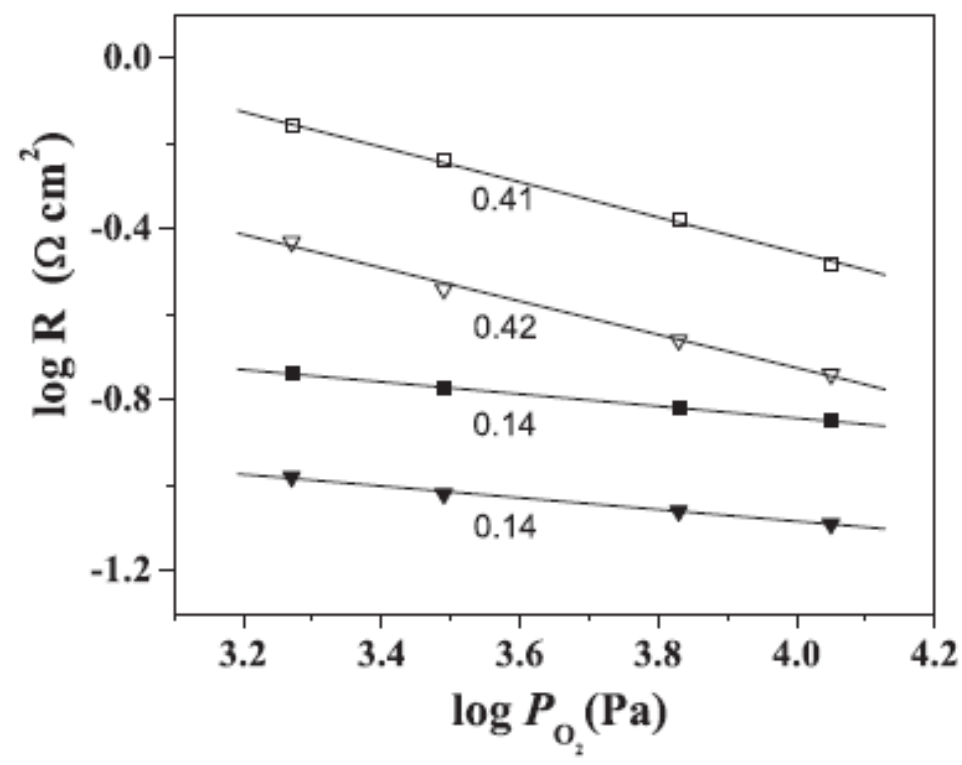

Figure 6: Polarization resistance of SCC-CGOo6 electrode vs. $\mathrm{PO}_{2}$ at various temperatures $\left(\square \mathrm{R}_{H} 75 \mathrm{O}^{\circ} \mathrm{C}, \boldsymbol{\nabla} \mathrm{R}_{\mathrm{H}}\right.$ $\left.700{ }^{\circ} \mathrm{C}, \square R_{L 75 O}{ }^{\circ} \mathrm{C}, \nabla R_{L} 700{ }^{\circ} \mathrm{C}\right)$. 
International Journal of Hydrogen Energy, 2011, 36(19), 12555-12560, doi: 10.1016/j.ijhydene.2011.07.001

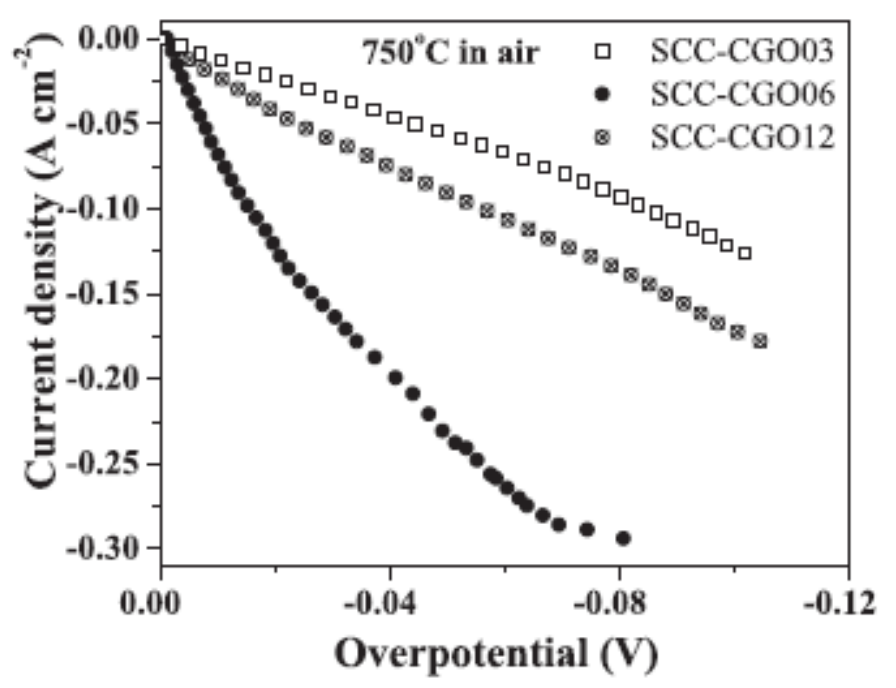

Figure 7: Polarization curves of SCC-CGOo6 composite electrode obtained at $750^{\circ} \mathrm{C}$ in air. 